\title{
SECOND HOME TOURISM: AN INTERCESSION FOR REJUVENETION OF TOURISM DESTINATION IN COVID-19 CRISIS
}

\author{
Manzuma Sharmin MUNNE* \\ National University of Bangladesh, Business Studies, Department of Tourism \& \\ Hospitality Management, Gazipur, Bangladesh, e-mail: sharmint17@gmail.com

\section{Shahariar HASAN} \\ National University of Bangladesh, Business Studies, Department of Tourism \& \\ Hospitality Management, Gazipur, Bangladesh, e-mail: du.shaown@yahoo.com

\section{Debasree BHOWMIK} \\ National University of Bangladesh, Business Studies, Department of Tourism \& \\ Hospitality Management, Gazipur, Bangladesh, e-mail: bhowmik_debasree@yahoo.com
}

\begin{abstract}
Citation: Munne, S.M., Hasan, S., \& Bhowmik, D. (2021). SECOND HOME TOURISM: AN INTERCESSION FOR REJUVENETION OF TOURISM DESTINATION IN COVID-19 CRISIS. GeoJournal of Tourism and Geosites, 38(4), 12651273. https://doi.org/10.30892/gtg. $38434-768$
\end{abstract}

\begin{abstract}
This study aims to demonstrate how hedonistic Second Home Tourism (SHT) trips and eudaimonic community participation will retrieve tourist flow and revive tourist destination from the COVID-19 crisis. Q methodology was followed to measure the subjectivity of scholars, researchers and practitioners of tourism industry for the appreciation of SHT in the crisis. Q Method Software was used to conduct factor analysis. The result of the study concludes that short haul mobility/trip within periphery and/or travel bubble accelerates the \% change of international tourist arrivals. The study also implores that how future SHT trips will ensure community resilience through social intuition (cultural integrity and knowledge exchange) and financial retention through economic empathy (demand-supply balance and revenue generation).
\end{abstract}

Key words: COVID-19 crisis, Second Home Tourism (SHT), tourist mobility, travel bubble, strategy

\section{INTRODUCTION}

Prolonged travel restriction has been imposed due to COVID-19 resulted ghost commercial flights and unimaginable drop of unemployment rate (Gallego and Font, 2021; Higgins-Desbiolles, 2020; Jamal and Budke, 2020). As increasing number of unemployment, global economic instability and unprecedented government interventions to economy has shaken the pillars of many tourism based countries, renovation of tourism industry is mandatory for the recovery of lost economy and the resilient of global instability (Higgins-Desbiolles, 2020). Longer quarantine has enforced the inactivity from participating in any festivals or sports (Chinazzi et al., 2020; Gössling et al., 2020). Similarly, heritage conservation, cultural and social fabric, indigenous handicraft market and indigenous women have been financially crippled due to COVID-19 crisis. $90 \%$ of countries had to close World Heritage Sites and around 85000 museums were shut down temporarily (UNWTO, 2020c). More than $30 \%$ of exports of Small Island Developing States and 80\% of exports of Least Developing and African countries are directly linked to tourism purposes (UNWTO, 2020c). However, Small Island Developing States have become ghost suburbs having $47 \%$ on tourist arrival (UNWTO, 2020d). Notably, Asia and Pacific region has experienced the hardest hit in 2020 and resulted the lowest international tourist arrival \% in 2020-2021 (Jan-Mar) due to COVID-19 crisis (UNWTO, 2021a). Tourism and hospitality industry has been on verge of irreparable losses of 1 billion loss on international tourist arrivals, 100-120 million direct tourism jobs at risk, US\$ 1.1 trillion loss in international tourism receipts, over US\$ 2 trillion loss of global GDP and lagged behind 1990s levels (UNWTO, 2020a). While UNWTO forecast $60 \%-80 \%$ recovery by 2020 , the pre-crisis level of tourist arrivals is expected to resume by the end of summer 2021 (Fotiadis et al., 2021). Later on, it is highlighted that the recovery of 2019 levels would take 2.5-4 years if the traveler confidence improvement rate, the travel restriction elimination and the prevailing economic condition are maintained globally (UNWTO, 2020e). This vulnerable structural break must be flipped by the strategic allocation of negative shocks in international tourism demand (Cro and Martins, 2017).

COVID-19 has devoured financial stability as well as created diversified social stigmas (e.g. religious \& racial discrimination, broken marriages, domestic violence, etc.) and psychological distresses (e.g. mass death, prolonged quarantine, abrupt unemployment, drastic financial loss, collapsed businesses, etc.) worldwide (Abbas et al., 2021). Trips for leisure and relaxation, mental health improvement, wellness trip or VFR gathering (Rogerson, 2016) have to be initiated to explore small islands beset with natural and cultural value instead of landscape-centric travel (Prince, 2018). As a form of "Territorial Tourism" with eco-friendly tourism infrastructure (Hoogendoorn and Fitchett, 2018), Second Home Tourism (SHT) will be a promising substitute for the mental health improvement and employee retention (Abbas et al., 2021). While international

\footnotetext{
* Corresponding author
} 
tourists are prohibited to travel and domestic tourist are interested to stay local residence (Liang et al., 2021), SHT would be a better alternative to dissolve the complexity of vacation rentals in either crowded cities or low density areas (Zogal et al., 2020). This attempt will enhance the financial recovery of the Local Economic Development (LED) and global tourism market (Farkić et al., 2020; Tangeland et al., 2013). In addition, hedonistic trip supports tourist wellbeing while eudaimonic dimensions encourage host perception patterns ( $\mathrm{Su}$ et al., 2020). Considering the context, the study aims to explore how hedonistic SHT trips and eudaimonic community behavior revitalize tourist destinations from COVID-19 crisis.

\section{Literature Review and Research Question Development}

Travel ban, Border restrictions, Closure of tourism facilities, Rescinding of consumer protection rights in hospitality and tourism, Reaction against Second Home and campervan owners, Return to the mothership, Confinement to residence/ tourism locations and penalties for non-compliances, Restrictions on VFR and Abuse of minorities are stated as the worst redemptions faced globally due to COVID-19 (Baum and Hai, 2020). As air and water travel (long haul trip) have been restricted (Chinazzi et al., 2020), local mobiles, car-based trip or bicycle (Back and Marjavaara, 2017) are considered for the flexible short haul trips. The purposes of SHT trip can be reconsidered based on personal or non-personal experiences to instigate new forms of SHT trip motivations such as nostalgic trip (historical or artificial) to hometown or historical places (Adams, 2020; Shi et al., 2021); mental association with a place or place image to visit or live in (Stylidis et al., 2021); socializing and home holiday/ vacation trip ( $\mathrm{Kr}$ et al., 2021); wellness trip (Page et al., 2017), spiritual experiences (Parsons et al., 2019), and mountain trip (Seraphin and Dosquet, 2020) are emphasized to improve physical and mental health.

RQ 1: Is it feasible to commence hedonistic SHT trip during and/or post COVID-19 crisis?

Revenue generations from tax and local consumption (direct interaction) and local firms and employees (indirect interaction) are shown as the positive impacts due to the arrival of SHT tourists (Larsson and Müller, 2019). Both Private sectors and Public sectors are mentioned as the beneficiaries of SHT (Larsson and Müller, 2019). The approximate negative impacts for heterogeneous tourist mobility are: fluctuation in investments, finance, labor markets (Back, 2020); endangered social and community capital (Gallent, 2014); socio-spatial differences, social conflicts and urban heterogeneity (Wu et al., 2015). It is a matter of concern that younger segment holds negative perception of SH due to the increasing housing pricing (Dutt et al., 2018). However, trips close to nature are suggested to strengthen social interactions and community identity (Rantala and Puhakka, 2019). It is proposed that nature based tourism activity products (e.g. learning, adventure, hunting) can be utilized to capture SHT market (Tangeland et al., 2013). Besides, SHT is suggested to be launched with strict and limited mobility, small tax or symbolic member fee and integration between SH communities (for physical attributes, stakeholders' participation and community acceptance) and SH ownership (for social, economic and cultural issues) (Dykes and Walmsley, 2015).

RQ 2: Can cultural integrity and knowledge exchange be revived by SHT tourists? RQ 3: Can SHT escalate economic regrowth of a tourist destination?

COVID-19 is defined as a Black Swan Event and envisioned for the acceleration of global climate recovery and economic reconstruction (Prideaux et al., 2020). Tourist destination drives are emphasized to be synchronized and stimulated for the reconstruction of economic diversification from any climate change or pandemic crisis through the new tourism opportunities and scopes (Hall et al., 2020). For instance, Nature, Rural tourism and Road-trips are prioritized due to travel limitations and quest for open-air experiences (UNWTO, 2020a); Adventure sports or recreations in nature are found significant for the development of hedonic and eudaimonic experiences between tourists and hosts significantly (Houge Mackenzie and Brymer, 2020; Houge Mackenzie and Hodge, 2020). Besides, tourists' mental and physical health can be ensured by the implementation of green orientation and sustainable practices following Lifestyle of Health and Sustainability (LOHAS) approach (Osti and Goffi, 2021). It is inferred that polished strategies can be injected for the global recurrence of the green growth or the decoupling economy towards sustainable tourism in lieu of enforced critics for massive tourism development and (over)tourism (Çakar and Uzut, 2020; Fletcher et al., 2019; Higgins-Desbiolles, 2020). For instance, "Strategic Emerging" market approach for China, India and Southeast Asia (Ioannides and Gyimóthy, 2020); "Future-Back approach" for the identification of operational gaps and resolve them (Haywood, 2020); "Local-centered tourism approach" for the adaptation of socially inclusive model and community wellbeing (Higgins-Desbiolles et al., 2019); "Slow travel" for the rejuvenation of nature and visitor experiences, and the improvement of eudaimonic wellbeing (Farkić et al., 2020); Liminal mobility for lifestyle migration facilitates tourism businesses (Nelson et al., 2021); Reshaping rural housing for profitable second-home hotspot (Gallent and Hamiduddin, 2021) as a form of "small tourism" (Bærenholdt et al., 2021); Diasporic tourism for the holistic benefits (Li et al., 2020).

RQ 4: How does SHT recreate tourism competitiveness from the hardest hit by COVID-19 crisis?

A roadmap is interpreted for sustainable and inclusive tourism sector defining: Managing the crisis and mitigating the socio-economic impacts on livelihoods; Boosting competitiveness and building resilience; Advancing innovation and the digitization of the tourism ecosystem fostering; Fostering sustainable and inclusive green growth; Strengthening coordination, partnerships and solidarity for socio-economic recovery (UNWTO, 2020c). Similarly, three trends of postCOVID-19 tourism are denoted for dynamic operation and future development. They are: Digital Intellectualization; Green, healthy and eco-friendly tourism product; and Popularity of new tourism like medical tourism, health tourism, rural tourism etc. (Chen et al., 2020). In addition, Community-Centered Tourism framework can be followed to restart tourism, adapt with environment, generate revenue and reduce overall losses (Higgins-Desbiolles, 2020). Comparing these footsteps, domestic tourism must be acknowledged by government and residents as the fastest recovery of tourism led to regular flow as before (Prideaux et al., 2020). SHT can be launched as either "Sharing Economy" or "Collaborative Economy" within 
domestic and/or travel bubble territories (Ioannides et al., 2019). Despite the bio-physical and socio-cultural impact of leisure oriented mobility for SHT trips, long haul SHT trips are referred as more sustainable than frequent short haul trips (Hiltunen and Rehunen, 2014). Nonetheless, SHT as "umbrella concept" can be thrived for unique attractiveness, flexible accessibility, historical significance and economic viability (Back and Marjavaara, 2017).

RQ 5: How does SHT encourage tourism clusters for the regeneration of socio-economic recovery from COVID-19 crisis?

Table 1. Literature reviews on LMT, SHT, ST, TCDM and US

\begin{tabular}{|c|c|c|c|c|c|c|c|c|c|c|}
\hline 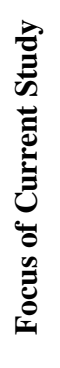 & 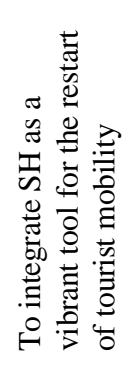 & 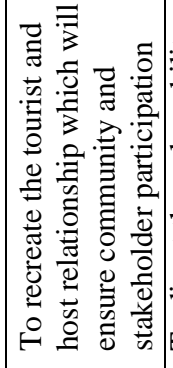 & 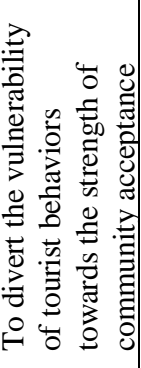 & 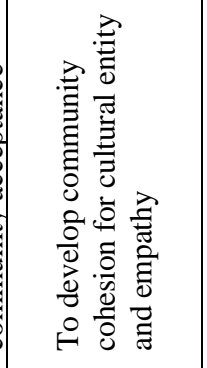 & 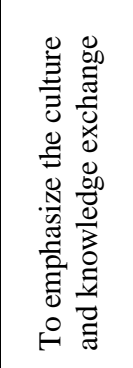 & \multicolumn{2}{|c|}{ 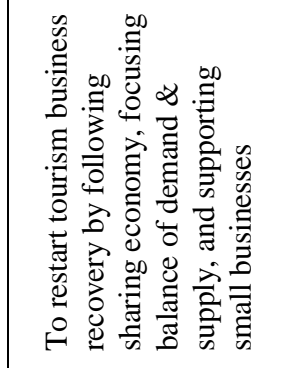 } & 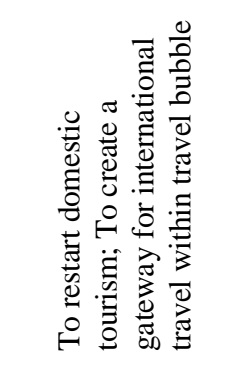 & 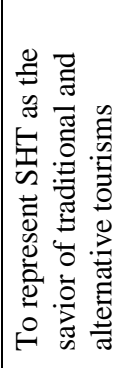 & 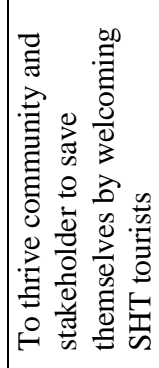 \\
\hline 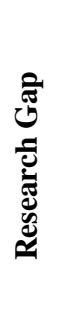 & 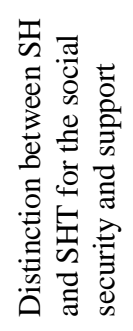 & 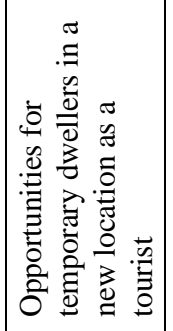 & 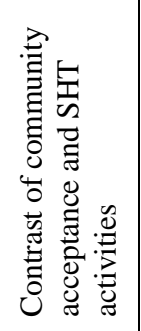 & 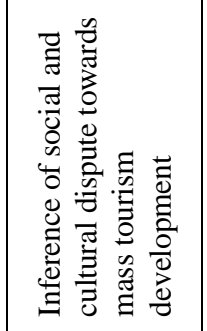 & 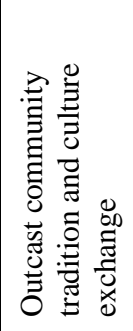 & \multicolumn{2}{|c|}{ 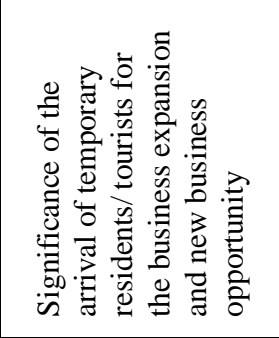 } & 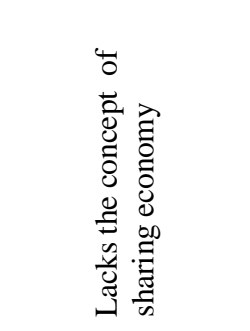 & 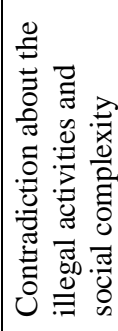 & 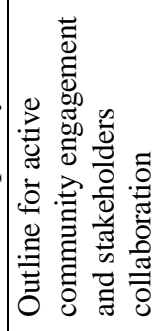 \\
\hline 最 & 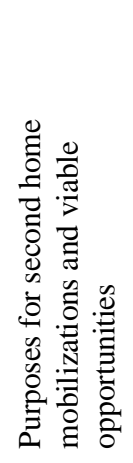 & 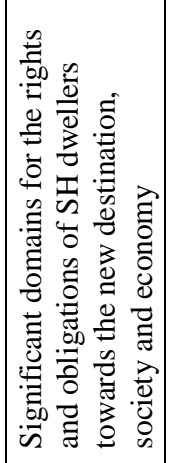 & 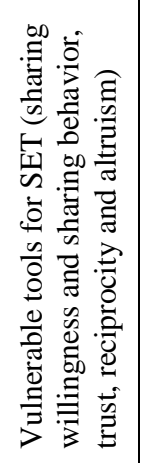 & 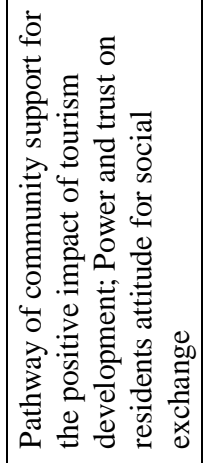 & 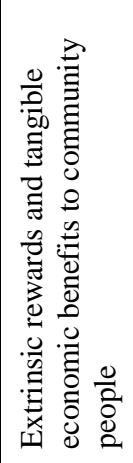 & 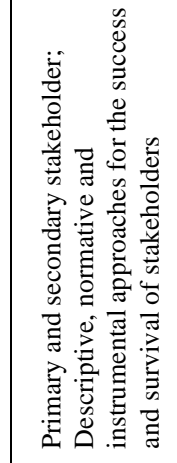 & 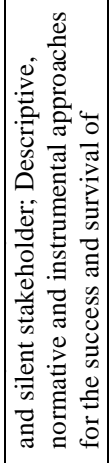 & 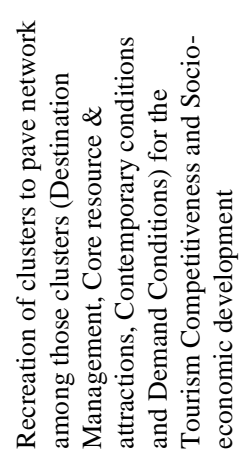 & 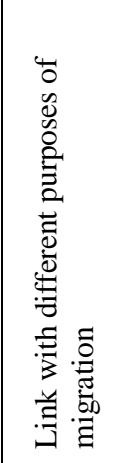 & 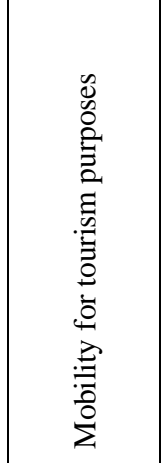 \\
\hline 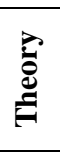 & \multicolumn{2}{|c|}{ 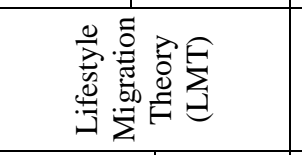 } & \multicolumn{3}{|c|}{ 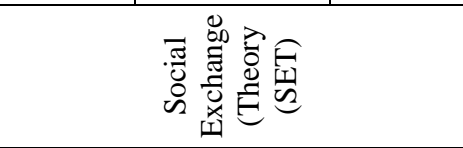 } & \multicolumn{2}{|c|}{ 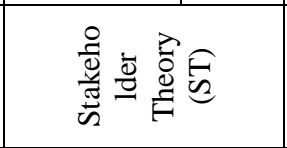 } & 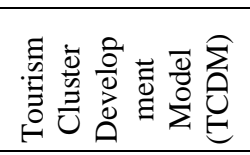 & \multicolumn{2}{|c|}{ 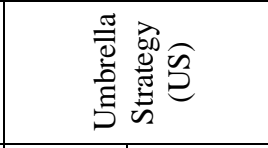 } \\
\hline$\stackrel{\bar{E}}{\dot{E}}$ & 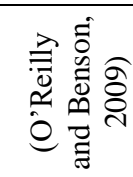 & 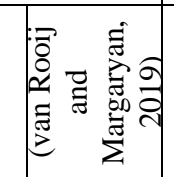 & 离命 & 总完 & 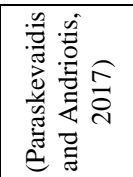 & 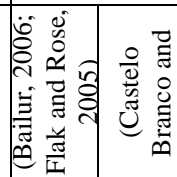 & 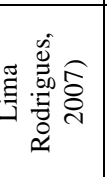 & $\begin{array}{l}0 \\
0 \\
0\end{array}$ & 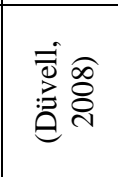 & 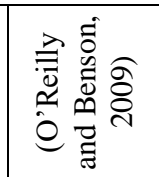 \\
\hline
\end{tabular}

\section{METHODOLOGY OF THE STUDY}

Q methodology was followed to conduct the study. Purposive sampling method was used to analysis the subjectivity of 37 respondents (25 Subject matter experts: such as 3 from Archeology, 4 from Heritage \& Culture Preservation, 2 from History and Culture, 4 from Indigenous Community, 10 from Rural Community Development, 2 from Creative City Planning; 7 Researchers and 5 Practitioners of tourism industry). Respondents are chosen from LinkedIn and are requested to participate in the online survey within June-July, 2021. Q Method Software (online) was used to run factor analysis. Relevant elements for the factor analysis are: Forced Q-sort (5 points scale: Strongly Disagree = -2, Disagree = -1, Neutral = 0, Agree = 1, Strongly Agree $=+2$ ), Q-sort $=37$ (No. of participants), Concourses/Q-set $=6$ (Statements), Correlation method =Pearson Correlation, Factor extraction method $=$ Principal Component Analysis $(\mathrm{PCA})$, Rotated factor $=3$, Rotation method $=$ Varimax, Flagging $=\mathrm{p}<0.05$. A number of 6 statements were developed to measure the subjective levels of participants. Table 1 is the summary of the pros and cons for adapting theories and model linked to SHT and Table 2 is the summary of the rational elements for the study.

\section{Data Analysis and Interpretation}

First, the significant factors are distinguished by comparing the Eigenvalues (value $\geq 1$ ). Table 3 shows that only Factor 1,2 and 3 had the required eigenvalues. Secondly, the impacts of significant factors are measured by relating the correlation 
factor loading. The correlation factor loading of the study is 0.80 [when $\mathrm{p}<0.05$, q-set $=6$ then equation is $1.96 *(1 / \sqrt{ } 6)$ ]. It implies that if a factor has correlation factor loading $\geq 0.80$, it has high impact. Factor 1 has the highest factor loading range of 0.90-0.96. Factor 2 has factor loading range respectively $0.84-0.94$. However, Factor 3 has both positive (0.95) and negative (0.84) factor loading. Lastly, the distinguishing and consensus statements are identified to secure reliability of the study shown in Table 4. Here, distinguishing statement characterizes a factor from another factor and consensus statement symbolizes the insights of the participants (e.g. logics for the perceived statement, issues related to the context of the statement).

Table 2. Elements of the Study

Statement/ Concourse Short haul transport would be
flexible than long haul transport

Local accommodation would be more comfortable than guaranteed reservation

Cultural integrity would scrutinize community disputes Knowledge exchange would be
more concerned than social ambiguity

Supply of local demand would

be important than the additional demands

Revenue generation would outcast employment generation

\section{Explanation for Statement selection}

Short haul transport is emphasized to appreciate limited mobility for SHT trips and to initiate domestic tourism; long haul transport is prioritized to focus on trips within travel bubble

Local accommodation is pointed to strengthen interaction between host and SHT tourists. However, reservation in hotel and/or resort might provide customized services to tourists and recover hotel economic loss

Fusion of community acceptance and residents engagement is defined as Cultural integrity. Here, community disputes are considered as the discreet negative impacts on host community due to the arrival of SHT tourists.

Knowledge exchange is considered as the silent drive for SHT relied on the purpose of trip. Besides, tourist behavior, attitude and acceptance towards the host community were considered to define social ambiguity.

Supply of additional demands (daily goods \& medical services) is considered significantly to balance the relationships among tourists, host community and local stakeholders.

Revenue generation is considered as key stimulus to community residents, small business owners and service providers. Here, exiled employees of hospitality \& aviation industries might interest to contribute community and local businesses rather than back to job again in same organization with insecurity.
Linked Theory

LMT, ST

LMT, SET, ST

SET, ST

SET, LMT

ST, LMT

ST, SET

Table 3. Rotated Factor Matrix

\begin{tabular}{|l|c|c|c|c|c|c|}
\hline & Factor 1 & Factor 2 & Factor 3 & Factor 4 & Factor 5 & Factor 6 \\
\hline Eigenvalues & 4.05467 & 2.78005 & 1.54118 & 0.94776 & 0.67633 & 0 \\
\hline \% Explained Variance & 41 & 28 & 15 & 9 & 7 & 0 \\
\hline Cumulative \% Expln Var & 41 & 68 & 84 & 93 & 100 & 100 \\
\hline
\end{tabular}

\section{DISCUSSION}

\section{SHT: A Road to Restart Tourism}

On-site travel experience is highlighted to reopen tourist destinations (Yang et al., 2021). Six dimensions of home-sharing stay are identified to demonstrate authentic tourism experience (space presence, social presence and knowledge sharing) and cultural experience (activity sharing, host interaction and guest interaction) significantly ( Shi et al., 2019). Besides, reimagining multiple factors are marked mandatorily for the revolution of home sharing, such as, motivations (working and sharing, host integrity and guest support), shared spaces (cleanliness, amenities, privacy, physical barriers and potential proximity), cultures (trust, value and social aspects), platforms (brand impression, customer support service and policy) (Lim et al., 2021). Participants of the study shared their insights to revive the tourist flow and recover financial losses. Table 4 resembles the answers of three research questions of the study. They are: 1 . Short haul mobility would be feasible for SHT trips and local residency would be better choice for accommodation, 2 . SHT tourists would encourage community engagement for cultural integrity and knowledge exchange separately or simultaneously, 3. SHT tourists would be viable for economic regrowth by the alliance of cultural integrity and knowledge exchange. Here, authentic tourism experience can be compared with the hedonistic SHT trips and cultural experience can be referred to eudaimonic community participation.

Table 4. Factor affecting the significance of Statements

\begin{tabular}{|l|c|c|c|c|c|c|c|c|c|}
\hline \multicolumn{1}{|c}{ Statements/ Concourses } & \multicolumn{3}{|c|}{ Factor 1 } & \multicolumn{3}{c|}{ Factor 2 } & \multicolumn{3}{c|}{ Factor 3 } \\
\cline { 2 - 11 } & Z-score & $\begin{array}{c}\text { Factor } \\
\text { Score }\end{array}$ & Significance & Z-score & $\begin{array}{c}\text { Factor } \\
\text { Score }\end{array}$ & Significance & Z-score & $\begin{array}{c}\text { Factor } \\
\text { Score }\end{array}$ & Significance \\
\hline $\begin{array}{l}\text { Short haul transport would be more } \\
\text { flexible than long haul transport }\end{array}$ & 0 & 0 & Consensus & 0 & 0 & Consensus & 0 & 0 & Consensus \\
\hline $\begin{array}{l}\text { Local accommodation would be more } \\
\text { comfortable than guaranteed reservation }\end{array}$ & -1.2757 & -2 & Distinguishing & 0.20842 & 0 & & 0.58904 & 1 & \\
\hline $\begin{array}{l}\text { Cultural integrity would scrutinize } \\
\text { community disputes }\end{array}$ & -0.93413 & -1 & & 0.33695 & 1 & Distinguishing & -0.74508 & -1 & \\
\hline $\begin{array}{l}\text { Knowledge exchange would be more } \\
\text { concentrated than Social ambiguity. }\end{array}$ & 0.19752 & 0 & & -0.54537 & -1 & & -1.49017 & -2 & Distinguishing \\
\hline $\begin{array}{l}\text { Supply of local demand would be more } \\
\text { important than the additional demands }\end{array}$ & 1.47322 & 2 & & 1.50758 & 2 & & 0.31208 & 0 & Distinguishing \\
\hline $\begin{array}{l}\text { Revenue generation would outcast } \\
\text { employment generation }\end{array}$ & 0.53909 & 1 & & - & -2 & Distinguishing & 1.33413 & 2 & \\
\hline
\end{tabular}

Togetherness, continuity, place attachment and relaxation are found crucial for vacation rentals SH (Dias et al., 2015). Place attachment is mentioned specifically for the Lifestyle mobility to avoid conflicts (Cohen et al., 2015) and to create 
positive host-tourist interaction (Eusébio et al., 2018). Residents' participation in tourism recovery tactics is found crucial to reduce social costs and generate economic benefits in a tourist destination (Qiu et al., 2020). So, if cultural integrity is ensured by the community residence towards SHT tourists, traditional businesses will flourish in post COVID-19 period, community ambiguity will be reduced and revenue generation will be ensured. It is highlighted that residents 'negative impact perception must be operationalized to incorporate the cost and benefit (Gursoy et al., 2019). Leisure oriented lifestyle travel (structural, physical and social elements) is encouraged (Pavelka and Draper, 2015) and the social integration (emotional attachment, social participation and cultural adaptation) is prioritized (Zhang et al., 2020). It is stated that seasonal tourism employment can be ensured due to lifestyle mobility (Lundmark, 2006). Similarly, the attitude, commitment and employee career turnover intention can be outshined by the perceived risk of infection and job instability (Han et al., 2021). So, it can be said that social integration would create employment opportunity to unemployed resident with classic businesses or tourism activities without any insecurity of uncertain cutoffs. Knowledge exchange offered by the community residence towards SHT tourists may allow distributing local goods and services without any wastage or price hike. Then, social ambiguity among residents, businessmen and tourists will be resolved. Second Home stated as "a centre for Leisure and Recreation" while age, health and income generation are found important for the ownership satisfaction (Lundmark and Marjavaara, 2013). It is mentioned that lifestyle entrepreneurs can strengthen economic benefit and social bond in Lifestyle destinations; however, new owners are suggested to consider the income generation source (Su et al., 2020; Sun and Xu, 2017). The prospective consequences of SHT trips mentioned above hint three links with short haul mobility and SHT trips. Such as: (i) Direct link-community residents with cultural integrity and knowledge exchange, (ii) Indirect link- cultural integrity and knowledge exchange; community residence with revenue generation and demand supply balance, and (iii) Induced link- cultural integrity with revenue generation, knowledge exchange with demand-supply balance and revenue generation with demand-supply balance. As the ultimate motive of commencing short haul mobility is to support community and recover financial losses of a tourist destination, the purpose of SHT trips should be the core concern for short haul or long haul trip. Local residence would be better form of accommodation for SHT during/post pandemic period. Thus, small business owners would reopen and recover losses. In addition, unemployed employees may provide services to SHT tourists and earn livelihood.

\section{SHT: A Covenant Shade in COVID-19 Crisis}

The spatial-temporal arrangements of SHT are suggested to be reshaped during and/or post COVID-19 (Müller, 2021). As SHT is expected to contribute as sharing economy, TCDM model can be followed to reshape destination management and stakeholders' collaborations for the optimization of future tourism competitiveness and socio-economic recovery. $R Q .4$ and $R Q .5$ of the study are interpreted in the light of the modified TCDM model. For instance, Government should guide nonprofessional accommodation providers (e.g. short term rental, local residence in neighborhood, etc.) to maintain quality service, revive residents rights and ensure social justice by maximizing rental day limit, tax collection and safety regulations (Minoia and Jokela, 2021); offer incentives (e.g. tax breaks, land use restrictions) to investors (Brouder, 2020). Destination management organizations (DMO) might utilize mobility as an opportunity for the community wellbeing and socio-cultural resilience through the integration of cultural integrity, knowledge exchange and social intuition. Such as: Interactive training on future consumer food habit or efficient store performance for entrepreneurial orientations (Chien and Tsai, 2021); Organization of music festival in rural community for longer stay (Chiciudean et al., 2021); Implementation of "soft governance" for decision-making processes and destination management pluralisation (Dredge and Jamal, 2013); Short term hedonistic SHT trips to avoid language barriers and cultural shock (Abdul-Aziz et al., 2014). Nonetheless, forms of tourism market, destination image, collaboration among stakeholders and future trends are stated as vulnerable issues for the DMOs amid COVID-19 crisis (Zhang and Blasco, 2021). The identification of tourism-dependent businesses and the assessment of their performances are pointed out as a mandate to ensure business resilience of a tourist destination during pandemic crisis (Ntounis et al., 2021). It is noted that the importance of SHT can be eroded despite DMO unable to ensure regional tourist engagement (Keogh et al., 2020). Tourism stakeholders can probe SHT as a stimulator to redistribution of manpower and business opportunity from COVID-19 crisis. Such as: maintaining multilayer network of stakeholders for knowledge exchange and collaboration for funding (Cehan et al., 2021); building resource based organizational resilience for better HR practices (Su et al., 2021); sanction of monetary support for financial recovery, hotel operation and employees remuneration (Nicola et al., 2020). Thus, DMOs and stakeholders can maximize benefits by the structured negotiations of supply \& goods, marketing \& promotion, strategies \& policies and product creation (Cehan et al., 2021) and Collaboration with local, regional or national governments will recreate a neoliberalism environment through leveraging tax and adding incentives (Higgins-Desbiolles, 2020). Bioclimatic impacts, tourism amenities and cost of SH must be considered to remodel adaptive strategies and behaviors (Hoogendoorn and Fitchett, 2018). Meanwhile, focus on nostalgia and restorative experience are suggested to be adopted for marketing strategies during and post-lockdown (Ketter and Avraham, 2021). Nevertheless, retentive advertising, discounting and flexible cancellation policies are found significant to increase domestic tourists' booking intention positively (Volgger et al., 2021). Constant media coverage about COVID-19 is highlighted for the significant change in travel risk perception and travel behavior (Neuburger and Egger, 2021); however, physical factors are found influential for trip intention (Ahmad et al., 2021).

\section{CONCLUSION}

The study outcome would amalgamate new drives (social intuition, cultural integrity, economic empathy) to LMT, SET and ST. Such as: When SHT tourists will visit new and/or popular community, they will contribute LMT drives "facilitators", "social connection" and "markets and means" consciously or subconsciously (van Rooij and Margaryan, 2019). Consequently, local people can be motivated to reopen traditional and tourism related businesses which is closely linked ST drives such as 
business owners, customers/tourists, service providers/employees and suppliers/distributors (O'Reilly and Benson, 2009). As social interaction is probed as significant pull factor to purchase $\mathrm{SH}$, contemplation, physical fitness, adaptation to environment or skill development (Tangeland et al., 2013), the effect of community residents' power and trust must be phenomenal while supporting SET towards tourists (Nunkoo, 2016). Later on, the resident perception and attitude can be swapped by the economic benefit, environmental cost and socio-cultural cost (Özel and Kozak, 2017). However, Altruistic Surplus Phenomenon (ASP) is found as a better alternative than SET for the analogy between tourist and host if volunteer tourism is offered (Paraskevaidis and Andriotis, 2017). This study strongly concludes that SHT trips for Restart tourism supports the implication of three different theories (LMT, SET \& ST) to focus mental health improvement, community resilience and financial recovery.

The outcome of the study has multiple practical implications. First, the Travel Bubble strategy is probed as a better strategy than social distancing, tax reduction strategy and joint strategy for the post pandemic tourism recovery in Small Island Developing States (SIDS) (Gu et al., 2021). So, SHT can be offered to LED countries in Africa and Asia Pacific enriched. For instance, a number of new travel bubbles can be opened within (i) Madagascar, South Africa, Zimbabwe and Mozambique; (ii) Kenya, Uganda, Tanzania and Malawi; (iii) Vietnam, Cambodia, Thailand and Laos; (iv) Malaysia, Indonesia and Philippines; (v) Singapore, Sri Lanka and Maldives; etc. Here, home sharing or converted SH can be more flexible than new SH. Second, As UNTWO has pointed out Inbound, Outbound and Both destinations around the world, such as, 101 inbound destinations, 31 outbound destinations and 48 both inbound and outbound destinations (UNWTO, 2020b), the scope of short haul SHT trips and travel bubble SHT trips should be encouraged. Third, Proposed outlines would enlighten the sustainable destination governance and the notion of collaboration among tourism clusters for the strategic management of the tourist inflow, community resilience and socio-economic recovery. Such as, (i) Limited restrictions (e.g. relaxed visa restrictions, trip after vaccination) for travelling within any new travel bubbles; (ii) Engagement of community residence and SHT tourists for voluntary services (e.g. wild life preservation, handloom production, culinary training, herbal treatment, ethnic lifestyles, fund raising, etc.). Here, trip within travel bubble would either reduce vulnerability or threaten the competitiveness of the tourist destinations (Gallego and Font, 2019). Fourth, The study outcome demonstrates Regenerative Tourism "embracing alternative non-capitalist forms of ownership, non-monetary exchange and beneficial community-based development" (Sheller, 2021).

Here, sustainable travel modes can be augmented considering the sense of movement for tourists wellbeing, physical and mental health improvement (Weed, 2020). In addition, Specification of duration, Management of downtime, Preparations of emergencies, Tailoring of tourist sequences, Motivation for engagement and Implication of time in memorability are prerequisite for the recovery of tourist experiences and psychological improvement (Pearce, 2020). Thus, tourists psychological wellbeing will choreographed by the sense of belongingness to a social group (Farkić et al., 2020). However, health \& safety measures, consumer friendly cancellation policies, and availability of last minutes bookings must be considered for future consumers'. In addition, younger segments must be emphasized for future travel market and travel recovery rather than the mature travelers and retirees (UNWTO, 2020a). A number of significant limitations of the study are mentioned here. First, the sample size of the study was very small compared to other research methodology. Second, the outcome of the study was illustrated unanimously. Any community, destination or continent was not focused specifically. Third, potential recovery of a tourist destination was illustrated in light of the result of the study. However, the recovery entirely depends on the COVID-19 crisis situation and the collaboration among tourism clusters. As tourism industry is in vulnerable condition, any forms of tourism apart from SHT must be analyzed to recur as better solution for the economic recovery of tourist destinations. Different issues related to SHT and Restart Tourism must be focused for the regeneration of tourism competitiveness and socio-economic recovery from post pandemic situation.

\section{Disclosure Statement}

No potential conflict of interest was mentioned by the authors.

\section{REFERENCE}

Abbas, J., Mubeen, R., Terhemba, P., \& Raza, S. (2021). Exploring the impact of COVID-19 on tourism : transformational potential and implications for a sustainable recovery of the travel and leisure industry. Current Research in Behavioral Sciences, 2, 100033. https://doi.org/10.1016/j.crbeha.2021.100033

Abdul-Aziz, A.R., Loh, C.L., \& Jaafar, M. (2014). Malaysia's My Second Home (MM2H) Programme: An examination of Malaysia as a destination for international retirees. Tourism Management, 40, 203-212. https://doi.org/10.1016/j.tourman.2013.06.008

Adams, K.M. (2020). What western tourism concepts obscure : intersections of migration and tourism in Indonesia. Tourism Geographies, 1-26. https://doi.org/10.1080/14616688.2020.1765010

Ahmad, A., Jamaludin, A., Shaliza, N., Zuraimi, M., \& Valeri, M. (2021). Visit intention and destination image in post- Covid-19 crisis recovery. Current Issues in Tourism, 24(17), 2392-2397. https://doi.org/10.1080/13683500.2020.1842342

Back, A. (2020). Temporary resident evil? Managing diverse impacts of second-home tourism. Current Issues in Tourism, $23(11), 1328-1342$. https://doi.org/10.1080/13683500.2019.1622656

Back, A., \& Marjavaara, R. (2017). Mapping an invisible population: the uneven geography of second-home tourism. Tourism Geographies, 19(4), 595-611. https://doi.org/10.1080/14616688.2017.1331260

Bærenholdt, J.O., Fuglsang, L., \& Sundbo, J. (2021). A coalition for 'small tourism' in a marginal place: Configuring a geo-social position. Journal of Rural Studies, 87, 169-180. https://doi.org/10.1016/j.jrurstud.2021.09.010

Bailur, S. (2006). Using Stakeholder Theory to Analyze Telecenter Projects. Information Technologies and International Development, 3(3), 61. https://doi.org/10.1162/itid.2007.3.3.61

Baum, T., \& Hai, N.T.T. (2020). Hospitality, tourism, human rights and the impact of COVID-19. International Journal of Contemporary Hospitality Management. https://doi.org/10.1108/JJCHM-03-2020-0242 
Brouder, P. (2020). Reset redux : possible evolutionary pathways towards the transformation of tourism in a COVID-19 world. Tourism Geographies, 22(3), 484-490. https://doi.org/10.1080/14616688.2020.1760928

Çakar, K., \& Uzut, İ. (2020). Exploring the stakeholder's role in sustainable degrowth within the context of tourist destination governance: the case of Istanbul, Turkey. Journal of Travel and Tourism Marketing, 37(8-9), 917-932. https://doi.org/10.1080/10548408.2020.1782307

Castelo Branco, M., \& Lima Rodrigues, L. (2007). Positioning Stakeholder Theory within the Debate on Corporate Social Responsibility. EJBO-Electronic Journal of Business Ethics and Organization Studies.

Cehan, A., Eva, M., \& Iațu, C. (2021). A multilayer network approach to tourism collaboration. Journal of Hospitality and Tourism Management, 46, 316-326. https://doi.org/10.1016/j.jhtm.2021.01.006

Chen, H., Huang, X., \& Li, Z. (2020). A content analysis of Chinese news coverage on COVID-19 and tourism. Current Issues in Tourism, 1-8. https://doi.org/10.1080/13683500.2020.1763269

Chiciudean, D.I., Harun, R., Muresan, I.C., Arion, F.H., \& Chiciudean, G.O. (2021). Rural Community-Perceived Benefits of a Music Festival. Societies, 11(2), 1-13. https://doi.org/10.3390/soc11020059

Chien, S., \& Tsai, C. (2021). Entrepreneurial orientation, learning, and store performance of restaurant: The role of knowledge-based dynamic capabilities. Journal of Hospitality and Tourism Management, 46, 384-392. https://doi.org/10.1016/j.jhtm.2021.01.007

Chinazzi, M., Davis, J.T., Ajelli, M., Gioannini, C., Litvinova, M., Merler, S., Piontti, A.P.Y., Rossi, L., Sun, K., Viboud, C., Xiong, X., Yu, H., Halloran, M.E., Longini, I.M., \& Vespignani, A. (2020). The effect of travel restrictions on the spread of the 2019 novel coronavirus (COVID-19) outbreak. Science, 368(6489), 395-400. https://doi.org/10.1126/science.aba9757

Cohen, S.A., Duncan, T., \& Thulemark, M. (2015). Lifestyle Mobilities: The Crossroads of Travel, Leisure and Migration. Mobilities, 10(1), 155-172. https://doi.org/10.1080/17450101.2013.826481

Cro, S., \& Martins, A.M. (2017). Structural breaks in international tourism demand: Are they caused by crises or disasters? Tourism Management, 63, 3-9. https://doi.org/10.1016/j.tourman.2017.05.009

Dias, J.A., Correia, A., \& López, F.J.M. (2015). The meaning of rental second homes and places: the owners' perspectives. Tourism Geographies, 17(2), 244-261. https://doi.org/10.1080/14616688.2014.959992

Dredge, D., \& Jamal, T. (2013). Mobilities on the Gold Coast, Australia : implications for destination governance and sustainable tourism. Journal of Sustainable Tourism, 21(4), 557-579. https://doi.org/10.1080/09669582.2013.776064

Dutt, C.S., Harvey, W.S., \& Shaw, G. (2018). The missing voices in the perceptions of tourism: The neglect of expatriates. Tourism Management Perspectives, 26, 193-202. https://doi.org/10.1016/j.tmp.2017.10.004

Düvell, F. (2008). Clandestine migration in Europe. Social Science Information, 47(4), 479-497. https://doi.org/10.1177/0539018408096442

Dykes, S., \& Walmsley, A. (2015). The reluctant tourist? An exploration of second home owners' perceptions of their impacts on North Cornwall, UK. European Journal of Tourism, Hospitality and Recreation, 6(2), 95-116.

Eusébio, C., Vieira, A.L., \& Lima, S. (2018). Place attachment, host-tourist interactions, and residents' attitudes towards tourism development: the case of Boa Vista Island in Cape Verde. Journal of Sustainable Tourism, 26(6), 890-909. https://doi.org/10.1080/09669582.2018.1425695

Farkić, J., Filep, S., \& Taylor, S. (2020). Shaping tourists' wellbeing through guided slow adventures. Journal of Sustainable Tourism, 28(12), 2064-2080. https://doi.org/10.1080/09669582.2020.1789156

Flak, L.S., \& Rose, J. (2005). Stakeholder Governance: Adapting stakeholder theory to e-government. Communications of the Association for Information Systems, 16(1), 31. https://doi.org/10.17705/1CAIS.01631

Fletcher, R., Murray Mas, I., Blanco-Romero, A., \& Blázquez-Salom, M. (2019). Tourism and degrowth: an emerging agenda for research and praxis. Journal of Sustainable Tourism, 27(12), 1745-1763. https://doi.org/10.1080/09669582.2019.1679822

Fotiadis, A., Polyzos, S., \& Huan, T.T.C. (2021). The good , the bad and the ugly on COVID-19 tourism recovery. Annals of Tourism Research, 87, 103117. https://doi.org/10.1016/j.annals.2020.103117

Gallego, I., \& Font, X. (2019). Measuring the vulnerability of tourist destinations to the availability of air transport , using multi-criteria composite indexes. Jourral of Destination Marketing \& Managmention, 14, 100382. https://doi.org/10.1016/j.jdmm.2019.100382

Gallego, I., \& Font, X. (2021). Changes in air passenger demand as a result of the COVID-19 crisis: using Big Data to inform tourism policy. Journal of Sustainable Tourism, 29(9), 1470-1489. https://doi.org/10.1080/09669582.2020.1773476

Gallent, N. (2014). The Social Value of Second Homes in Rural Communities. Housing, Theory and Society, 31(2), $174-191$. https://doi.org/10.1080/14036096.2013.830986

Gallent, N., \& Hamiduddin, I. (2021). COVID-19, second homes and the challenge for rural amenity areas. Town Planning Review, 92(3), $395-401$. https://doi.org/10.3828/tpr.2020.41

Gössling, S., Scott, D., \& Hall, C.M. (2020). Pandemics, tourism and global change: a rapid assessment of COVID-19. Journal of Sustainable Tourism, 29(1), 1-20. https://doi.org/10.1080/09669582.2020.1758708

Gu, Y., Onggo, B.S., Kunc, M.H., Bayer, S., Gu, Y., Onggo, B.S., Kunc, M.H., \& Bayer, S. (2021). Small Island Developing States ( SIDS ) COVID-19 post-pandemic tourism recovery: A system dynamics approach Small Island Developing States ( SIDS ) COVID19 post-pandemic. Current Issues in Tourism, 1-28. https://doi.org/10.1080/13683500.2021.1924636

Gursoy, D., Ouyang, Z., Nunkoo, R., \& Wei, W. (2019). Residents' impact perceptions of and attitudes towards tourism development: a meta-analysis. Journal of Hospitality Marketing and Management, 28(3), 306-333. https://doi.org/10.1080/19368623.2018.1516589

Hall, C.M., Scott, D., \& Gössling, S. (2020). Pandemics, transformations and tourism: be careful what you wish for. Tourism Geographies, 22(3), 577-598. https://doi.org/10.1080/14616688.2020.1759131

Han, H., Koo, B., Ariza-montes, A., Lee, Y., \& Kim, H. (2021). Are airline workers planning career turnover in a post-COVID-19 world? Assessing the impact of risk perception about virus infection and job instability. Journal of Hospitality and Tourism Management, 48, $460-467$. https://doi.org/10.1016/j.jhtm.2021.08.003

Haywood, K.M. (2020). A post COVID-19 future - tourism re-imagined and re-enabled. Tourism Geographies, 22(3), 599-609. https://doi.org/10.1080/14616688.2020.1762120

Higgins-Desbiolles, F. (2020). Socialising tourism for social and ecological justice after COVID-19. Tourism Geographies, 22(3), 610-623. https://doi.org/10.1080/14616688.2020.1757748

Higgins-Desbiolles, F., Carnicelli, S., Krolikowski, C., Wijesinghe, G., \& Boluk, K. (2019). Degrowing tourism : rethinking tourism. Journal of Sustainable Tourism, 27(12), 1926-1944. https://doi.org/10.1080/09669582.2019.1601732

Hiltunen, M.J., \& Rehunen, A. (2014). Second home mobility in Finland: Patterns, practices and relations of leisure oriented mobile lifestyle. Fennia-International Journal of Geography, 192(1), 1-22. 
Hoogendoorn, G., \& Fitchett, J.M. (2018). Perspectives on second homes, climate change and tourism in South Africa. African Journal of Hospitality, Tourism and Leisure, 7(2), 1-18.

Houge Mackenzie, S., \& Brymer, E. (2020). Conceptualizing adventurous nature sport: A positive psychology perspective. Annals of Leisure Research, 23(1), 79-91. https://doi.org/10.1080/11745398.2018.1483733

Houge Mackenzie, S., \& Hodge, K. (2020). Adventure recreation and subjective well-being: a conceptual framework framework. Leisure Studies, 39(1), 26-40. https://doi.org/10.1080/02614367.2019.1577478

Ioannides, D., \& Gyimóthy, S. (2020). The COVID-19 crisis as an opportunity for escaping the unsustainable global tourism path. Tourism Geographies, 22(3), 624-632. https://doi.org/10.1080/14616688.2020.1763445

Ioannides, D., Röslmaier, M., \& van der Zee, E. (2019). Airbnb as an instigator of 'tourism bubble' expansion in Utrecht's Lombok neighbourhood. Tourism Geographies, 21(5), 822-840. https://doi.org/10.1080/14616688.2018.1454505

Jamal, T., \& Budke, C. (2020). Tourism in a world with pandemics: local-global responsibility and action. Journal of Tourism Futures, 6(2), 181-188. https://doi.org/10.1108/JTF-02-2020-0014

Jinyang, L. (2015). Knowledge sharing in virtual communities: A social exchange theory perspective. Journal of Industrial Engineering and Management, 8(1), 170-183. https://doi.org/10.3926/jiem.1389

Keogh, C., Kriz, A., Barnes, L., \& Rosenberger, P.J. (2020). Exploring destination engagement of sharing economy accommodation: case of Australian second-homes. Current Issues in Tourism, 1-18. https://doi.org/10.1080/13683500.2020.1769572

Ketter, E., \& Avraham, E. (2021). \#StayHome today so we can \#TravelTomorrow: tourism destinations' digital marketing strategies during the Covid-19 pandemic. Journal of Travel \& Tourism Marketing, 38(8), 1-14. https://doi.org/10.1080/10548408.2021.1921670

Kim, N., \& Wicks, B.E. (2010). Rethinking Tourism Cluster Development Models for Global Competitiveness.

Kr, J., Jacobsen, S., Farstad, E., Higham, J., Hopkins, D., \& Landa-mata, I. (2021). Travel discontinuities , enforced holidaying-at- home and alternative leisure travel futures after. Tourism Geographies, 1-19. https://doi.org/10.1080/14616688.2021.1943703

Larsson, L., \& Müller, D.K. (2019). Coping with second home tourism: responses and strategies of private and public service providers in western Sweden. Current Issues in Tourism, 22(16), 1958-1974. https://doi.org/10.1080/13683500.2017.1411339

Li, T.E., McKercher, B., \& Chan, E.T.H. (2020). Towards a conceptual framework for diaspora tourism. Current Issues in Tourism, 23(17), 2109-2126. https://doi.org/10.1080/13683500.2019.1634013

Liang, S., Leng, H., Yuan, Q., \& Yuan, C. (2021). Impact of the COVID-19 pandemic: Insights from vacation rentals in twelve mega cities. Sustainable Cities and Society, 74, 103121. https://doi.org/10.1016/j.scs.2021.103121

Lim, W.M., Yap, S.F., \& Makkar, M. (2021). Home sharing in marketing and tourism at a tipping point: What do we know, how do we know, and where should we be heading? Journal of Business Research, 122, 534-566. https://doi.org/10.1016/j.jbusres.2020.08.051

Lundmark, L. (2006). Mobility, migration and seasonal tourism employment: Evidence from swedish mountain municipalities. Scandinavian Journal of Hospitality and Tourism, 6(3), 197-213. https://doi.org/10.1080/15022250600866282

Lundmark, L., \& Marjavaara, R. (2013). Second Home Ownership: A Blessing for All? Scandinavian Journal of Hospitality and Tourism, 13(4), 281-298. https://doi.org/10.1080/15022250.2013.862439

Minoia, P., \& Jokela, S. (2021). Platform-mediated tourism : social justice and urban governance before and during Covid-19. Journal of Sustainable Tourism, 1-15. https://doi.org/10.1080/09669582.2021.1922426

Müller, D.K. (2021). 20 years of Nordic second-home tourism research : a review and future research agenda and future research agenda. Scandinavian Journal of Hospitality and Tourism, 21(1), 91-101. https://doi.org/10.1080/15022250.2020.1823244

Nelson, K., Black, R., \& Bamberry, L. (2021). Second life: Liminal tourism spaces as sites for lifestyle migration, an explor ation of Niseko, Japan. Journal of Hospitality and Tourism Management, 47, 294-302. https://doi.org/10.1016/j.jhtm.2021.04.001

Neuburger, L., \& Egger, R. (2021). Travel risk perception and travel behaviour during the COVID-19 pandemic 2020 : a case study of the DACH region. Current Issues in Tourism, 24(7), 1003-1016. https://doi.org/10.1080/13683500.2020.1803807

Nicola, M., Alsafi, Z., Sohrabi, C., Kerwan, A., Al-Jabir, A., Iosifidis, C., Agha, M., \& Agha, R. (2020). The socio-economic implications of the coronavirus pandemic (COVID-19): A review. International Journal of Surgery, 78, 185-193. https://doi.org/10.1016/j.ijsu.2020.04.018

Ntounis, N., Parker, C., Skinner, H., Steadman, C., Ntounis, N., Parker, C., Skinner, H., Steadman, C., Parker, C., Skinner, H., \& Steadman, C. (2021). Tourism and Hospitality industry resilience during the Covid-19 pandemic: Evidence from England. Current Issues in Tourism, 1-14. https://doi.org/10.1080/13683500.2021.1883556

Nunkoo, R. (2016). Toward a More Comprehensive Use of Social Exchange Theory to Study Residents' Attitudes to Tourism. Procedia Economics and Finance, 39, 588-596. https://doi.org/10.1016/S2212-5671(16)30303-3

O’Reilly, K., \& Benson, M. (2009). Lifestyle Migration: Escaping to the good life? IN: Benson, M. And O'Reilly, K. (eds) Lifestyle Migrations: Expectations, Aspirations and Experiences. Ashgate, 1-13.

Osti, L., \& Goffi, G. (2021). Lifestyle of health \& sustainability: The hospitality sector's s response to a new market segment. Journal of Hospitality and Tourism Management, 46, 360-363. https://doi.org/10.1016/j.jhtm.2021.01.008

Özel, Ç.H., \& Kozak, N. (2017). An exploratory study of resident perceptions toward the tourism industry in Cappadocia: a Social Exchange Theory approach. Asia Pacific Journal of Tourism Research, 22(3), 284-300. https://doi.org/10.1080/10941665.2016.1236826

Page, S.J., Hartwell, H., Johns, N., Fyall, A., Ladkin, A., \& Hemingway, A. (2017). Case study: Wellness, tourism and small business development in a UK coastal resort: Public engagement in practice. Tourism Management, 60, 466-477. https://doi.org/10.1016/j.tourman.2016.12.014

Paraskevaidis, P., \& Andriotis, K. (2017). Altruism in tourism: Social Exchange Theory vs Altruistic Surplus Phenomenon in host volunteering. Annals of Tourism Research, 62, 26-37. https://doi.org/10.1016/j.annals.2016.11.002

Parsons, H., Houge Mackenzie, S., \& Filep, S. (2019). Facilitating self-development : how tour guides broker spiritual tourist experiences experiences. Tourism Recreation Research, 44(2), 141-152. https://doi.org/10.1080/02508281.2019.1582159

Pavelka, J., \& Draper, D. (2015). Leisure negotiation within amenity migration. Annals of Tourism Research, 50, $128-142$. https://doi.org/10.1016/j.annals.2014.11.013

Pearce, P.L. (2020). Tourists perception of time: Directions for design. Annals of Tourism Research, 83, 102932. https://doi.org/10. 1016/j.annals.2020.102932

Prideaux, B., Thompson, M., \& Pabel, A. (2020). Lessons from COVID-19 can prepare global tourism for the economic transformation needed to combat climate change. Tourism Geographies, 22(3), 667-678. https://doi.org/10.1080/14616688.2020.1762117

Prince, S. (2018). Dwelling and tourism: embracing the non-representational in the tourist landscape. Landscape Research, 44(6), 731742. https://doi.org/10.1080/01426397.2018.1518520 
Qiu, R.T.R., Park, J., Li, S., \& Song, H. (2020). Social costs of tourism during the COVID-19 pandemic. Annals of Tourism Research, $84,102994$. https://doi.org/10.1016/j.annals.2020.102994

Rantala, O., \& Puhakka, R. (2019). Children's Geographies Engaging with nature: nature affords well-being for families and young people in Finland. Children's Geographies, 18(4), 490-503. https://doi.org/10.1080/14733285.2019.1685076

Rogerson, C.M. (2016). Secondary cities and tourism: The South African record. African Journal of Hospitality, Tourism and Leisure, 5(2), 1-12.

Seraphin, H., \& Dosquet, F. (2020). Mountain tourism and second home tourism as post COVID-19 lockdown placebo? Worldwide Hospitality and Tourism Themes, 12(4), 485-500. https://doi.org/10.1108/WHATT-05-2020-0027

Sheller, M. (2021). Reconstructing tourism in the Caribbean: connecting pandemic recovery , climate resilience and sustainable tourism through mobility justice. Journal of Sustainable Tourism, 29(9), 1436-1449. https://doi.org/10.1080/09669582.2020.1791141

Shi, S., Gursoy, D., \& Chen, L. (2019). Conceptualizing home-sharing lodging experience and its impact on destination image perception: A mixed method approach. Tourism Management, 75, 245-256. https://doi.org/10.1016/j.tourman.2019.05.012

Shi, Y., Bettache, K., Zhang, N., \& Xue, L. (2021). Constructing nostalgia in tourism: A comparison analysis of genuine and artificial approaches. Journal of Destination Marketing and Management, 19, 100488. https://doi.org/10.1016/j.jdmm.2020.100488

Stylidis, D., Cherifi, B., \& Melewar, T.C. (2021). Exploring Czechs' and Greeks ' mental associations of London : A tourist destination or a place to live in ? Journal of Destination Marketing \& Management, 19, 100530. https://doi.org/10.1016/j.jdmm.2020.100530

Su, D.N., Tra, D.L., My, H., Huynh, T., Hong, H., Nguyen, T., \& Mahony, B.O. (2021). Enhancing resilience in the Covid-19 crisis: lessons from human resource management practices in Vietnam. Current Issues in Tourism, 24(22), 3189-3205. https://doi.org/10.1080/13683500.2020.1863930

Su, L., Tang, B., \& Nawijn, J. (2020). Eudaimonic and hedonic well-being pattern changes : Intensity and activity. Annals of Tourism Research, 84, 103008. https://doi.org/10.1016/j.annals.2020.103008

Su, X., Zhang, H., \& Cai, X. (2020). Lifestyle, profit, and the selling of home to tourists in Lijiang, China. Tourism Geographies, 23(56), 1001-1020. https://doi.org/10.1080/14616688.2019.1708447

Sun, X., \& Xu, H. (2017). Lifestyle tourism entrepreneurs' mobility motivations: A case study on Dali and Lijiang, China. Tourism Management Perspectives, 24, 64-71. https://doi.org/10.1016/j.tmp.2017.06.004

Tangeland, T., Vennesland, B., \& Nybakk, E. (2013). Second-home owners' intention to purchase nature-based tourism activity products - A Norwegian case study. Tourism Management, 36, 364-376. https://doi.org/10.1016/j.tourman.2012.10.006

van Rooij, N., \& Margaryan, L. (2019). Integration of "Ideal Migrants": Dutch lifestyle expat-preneurs in Swedish campgrounds. Rural Society, 28(3), 183-197. https://doi.org/10.1080/10371656.2020.1718329

Volgger, M., Taplin, R., \& Aebli, A. (2021). Recovery of domestic tourism during the COVID-19 pandemic : An experimental comparison of interventions. Journal of Hospitality and Tourism Management, 48, 428-440. https://doi.org/10.1016/j.jhtm.2021.07.015

Weed, M. (2020). The role of the interface of sport and tourism in the response to the COVID-19 pandemic. Journal of Sport \& Tourism, 24(2), 79-92. https://doi.org/10.1080/14775085.2020.1794351

Wu, Y., Xu, H., \& Lew, A.A. (2015). Consumption-led mobilized urbanism : socio-spatial separation in the second-home city of Sanya. Mobilities, 10(1), 136-154. https://doi.org/10.1080/17450101.2013.853952

Yang, Y., Ruan, Q., Sam, S., Lan, T., \& Wang, Y. (2021). Impact of the COVID-19 outbreak on tourists ' real-time on-site emotional experience in reopened tourism destinations. Journal of Hospitality and Tourism Management, 48, 390-394. https://doi.org/10.1016/j.jhtm.2021.07.014

Zhang, H., Yan, L., Lee, H.M., \& Yang, Q. (2020). Social integration of lifestyle migrants: the case of Sanya snowbirds. Current Issues in Tourism, 23(22), 2825-2838. https://doi.org/10.1080/13683500.2020.1797646

Zhang, Y., \& Blasco, D. (2021). Destination management amid COVID-19: a case study in La Cerdanya, Spain. Anatolia, 1-12. https://doi.org/10.1080/13032917.2021.1920439

Zogal, V., Domènech, A., \& Emekli, G. (2020). Stay at ( which ) home : second homes during and after the COVID-19 pandemic. Journal of Tourism Futures. https://doi.org/10.1108/JTF-06-2020-0090

*** UNWTO. (2020a). COVID-19 and Tourism, 2020: A year in review.

*** UNWTO. (2020b). COVID-19 related travel restrictions - A global review for tourism, 8th Report (Issue December).

*** UNWTO. (2020c). Policy Brief: Covid-19 and Transforming Tourism (Issue August).

*** UNWTO. (2020d). Tourism in SIDS : the challenge of sustaining livehoods in times of COVID-19. In UNWTO Briefing NoteTourism and COVID-19 (Issue 2).

*** UNWTO. (2020e). World Tourism Barometer August/September, 2020, 18(5).

*** UNWTO. (2021). UNWTO World Tourism Barometer and Statistical Annex, May 2021. UNWTO World Tourism Barometer 19(3).

Article history: Received: 14.07.2021 Revised: 11.10.2021 Accepted: 16.11.2021 Available online: 09.12.2021 